原 著

\title{
MR 画像において伝導性サンプルの受信感度に与える影響
}

\author{
宮 地 利 明・笠 井 治昌 - 榊 原 利 陽 \\ 市 川勝弘・廣 瀬 保次郎・八 神 祐 司 \\ 神 谷誠一・春藤 英 雄 - 今 澤 正 好 \\ 荒 木 克 己*
}

名古屋市立大学病院中央放射線部

*名古屋市総合リハビリテーションセンタ放射線診断部

（論文受理 1992年 6 月 4 日）

（最終論文受理１993年 2 月19日）

(Code No. 261, 525, 761, 860, 924)

Key words : Magnetic resonance imaging (MRI), Image quality, Quality control, Radio-frequency coil, Magnetic loss

\section{EFFECT OF CONDUCTIVE SAMPLES ON RECEIVING SENSITIVITY IN MAGNETIC RESONANCE IMAGING}

\author{
Toshiaki Miyachi, Harumasa Kasai, Toshiaki Sakakibara \\ Katsuhiro Ichikawa, Yasujiroh Hirose, Yuji Yagami \\ Masakazu Kamiya, Hideo Shundo, Masayoshi Imazawa \\ Katsumi Araki* \\ Department of Radiology, Nagoya City University Hospital \\ *Department of Radiology, Nagoya Rehabilitation Center
}

\begin{abstract}
Summary
A study was carried out on studied the effects of conductive samples regarding experimental receiving sensitivity on $0.5 \mathrm{~T}$ magnetic resonance imaging (MRI) system and the adaptability of these results to clinical imaging. The relationship among the sample size, conductivity and inductive loss (magnetic loss) was taken up.

For the $0.5 \mathrm{~T}-\mathrm{MRI}$ system, inductive loss was in proportion to the electric conductivity of the sample and to the fifth power of the sample radius. Furthermore, the second power of the signal-to-noise ratio(SNR) of the image was inversely proportional to the fifth power of the sample radius. These results agreed well with the
\end{abstract}


theoretical formulations. In addition, the maximum and minimum receiving sensitivity of each radio-frequency (RF) coil could be calculated from the ratio of the inductive losses observed.

The experimental results could be applied for clinical imaging. Values for the observed inductive losses in human subjects reflected the characteristics of the particular organ being evaluated, and also reflected the characteristics of the particular RF coils. Calculating the inductive loss value in reference to the particular body part allowed for practical estimation of the coil parameters, and was useful in assurance of image quality.

\section{1. 緒言}

Magnetic resonance imaging（以下 MRI と略す）に おいて，伝導性サンプルである生体の損失秩序を求める ことは，受信感度および画質を考える上で重要である。 Hoult と Lauterbur は，伝導性サンプルが伴う場合にお ける種々の効果を, $10 \mathrm{MHz}$ 以下の MRI において詳細 に述べている1).我及はこの論文中の式 $1 ， 2 ， 3$ に示す 関係に注目し, 被検体の電気伝導率 $\sigma$ と寸法 $\mathrm{b} お$ よび radio frequency（以下 RF と略す）コイル寸法a の，誘 導損失性抵抗 $R m$ に対する関与ならびに信号雑音比（以 下 SN 比と略す) $\psi$ への寄与について実測した。この結果 より，上記理論の静磁場強度 $0.5 \mathrm{~T}$ 装置への適用の是非 を確認した。さらに理論を人体に適応させ，コイルパラ メータの設定扔よび画質管理等の臨床応用について示し た.

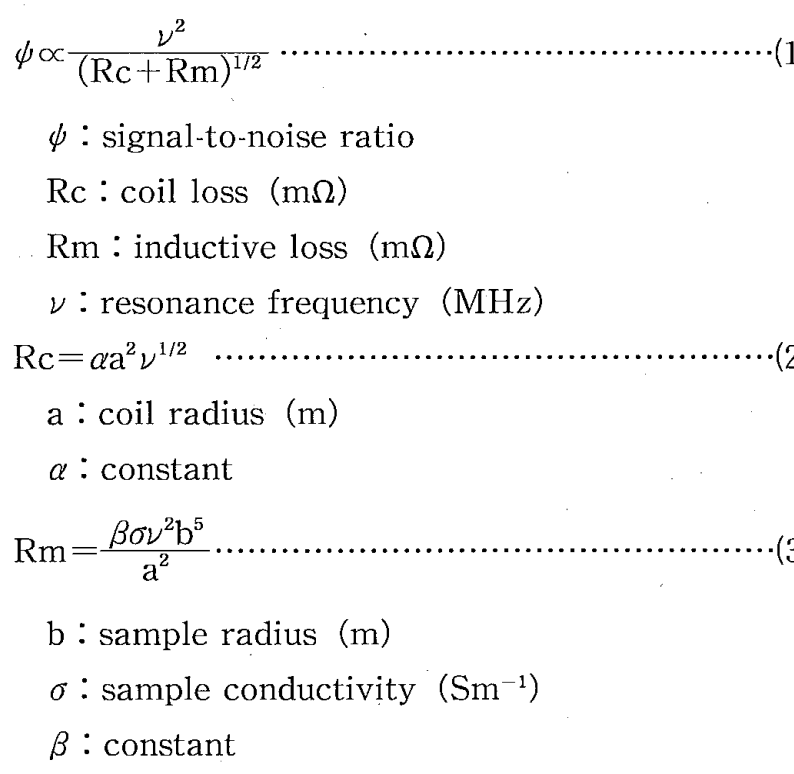

\section{2. 方 法}

実験装置は，Gyroscan S5（Philips 社製-静磁場強度 $0.5 \mathrm{~T})$ である. RF コイルはサドル型シングルコイル方 式で，頭部用コイル (容積 $\left.\fallingdotseq 29 \mathrm{dm}^{3}\right)$ と全身用コイル（容 積 $\fallingdotseq 130 \mathrm{dm}^{3}$ ) を使用した。半径の異なる数種のポリエチ レン円筒容器に電解質（塩化ナトリウムもしくは硫酸銅
溶液）を満たし (サンプル)，マグネットの長軸と同一軸 上に配置した。

溶液の電気伝導率は，2電極セルを用いたコールラウ シュブリッジ法で測定した。

コイル抵抗 $(\mathrm{Rc}+\mathrm{Rm})$ は以下の様にして求めた。 $\mathrm{RF}$ コイルの可変コンデンサのチューニング容量, マッチン グ容量をステッピングモータによって変化させながら調 律した。 その際共振曲線をスイープさせて中心周波数 $\nu$ と振幅の最大值より $3 \mathrm{~dB}$ 低い带域幅 $\Delta \nu$ を測定し, $\nu$ と

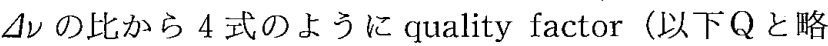
す）を求めた

$$
\mathrm{Q}=\frac{\nu}{\Delta \nu}
$$

これよりコイル抵抗は，Qおよび中心周波数 $\nu$ とコンデ ンサ容量Cの積の逆数として 5 式から算出した ${ }^{(2)}$.

$\mathrm{Rc}+\mathrm{Rm}=\frac{1}{\nu \mathrm{CQ}}$

コイル抵抗の表示は，誘導損失性抵抗の比較を容易にす るために，サンプルがない状態を 1 としたときの相対值 とした.

以上の測定条件および方法によって下記の実験を行な った.

\section{1 予備測定}

サンプルの電気伝導率とコイル抵抗の関係を測定した. また電気的に人体が50 $100 \mathrm{mmol} \cdot \mathrm{dm}^{-3}$ の濃度の湓化

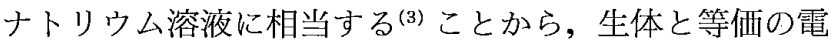
気伝導率を求めた. $5 \mathrm{dm}^{3}$ 抢よび $10 \mathrm{dm}^{3}$ の塩化ナトリウ ム溶液において測定を行なった。

\section{2 理論の検証}

\section{2 .1 誘導損失性抵抗（コイル抵抗）}

予備測定で求めた人体等価電気伝導率に調整した硫酸 銅溶液 $\left(0.8 \mathrm{Sm}^{-1}\right)$ と, $0.3 \mathrm{Sm}^{-1}$ および $0.1 \mathrm{Sm}^{-1}$ に調整 した硫酸銅溶液を使用した。 サンプルの半径を変化させ た時のQを，頭部用および全身用コイルにおいて測定し た，Qの測定值抢よびその際の中心周波数とコンデンサ 容量から，サンプルの半径が変化した場合に扔けるコイ ルの抵抗值を算出した（式５）. 


\section{$2.2 .2 \mathrm{SN}$ 比}

コイル抵抗測定と同様の状態において，サンプルの半 径を変化させた時の画像のSN 比を測定した。 SN 比測 定は, National Electrical Manufactures Association (以下 NEMA と略す) Standards Publication $の$ MS 1 に従って測定しだ).

\section{3 臨床適応}

実際に人体が RF コイル中に位置する場合のコイル抵 抗を, 頭部用コイル（頭部，搷部，䎑部）と全身用コイ ル（胸部，腹部，骨盤部）において測定した。整位はマ グネット中心に対して，各部位ごとに一定とした．頭部 は外眼角, 頚部は耳孔と鎖骨の中点, 㯟部は㯟関節, 胸 部は鎖骨と剣状突起の中点, 腹部は剣状突起と腸骨陵上 縁の中点，骨盤部は上前腸骨棘を中心とした。また磁場 中心を基準にして，長軸方向の一定範囲（頭部用コイル $\cdots 100 \mathrm{~mm}$ ，全身用コイル $\cdots 170 \mathrm{~mm}$ ）における被検体の 横断面上の半径抢よび面積の平均值を, 実効半径, 実効 面積とした。

\section{3. 結 果}

\section{1 予 備 測 定}

サンプルの電気伝導率とコイル抵抗の関係を Fig. 1 に示す.サンプル容積が大きいほど, コイル抵抗の増加 率は大きかった.コイル抵抗のデータを，塩化ナトリウ ム溶液の電気伝導率に回帰させた結果, Table 1 の 1 の ごとくなった。また, 生体等価濃度の溶液の電気伝導率

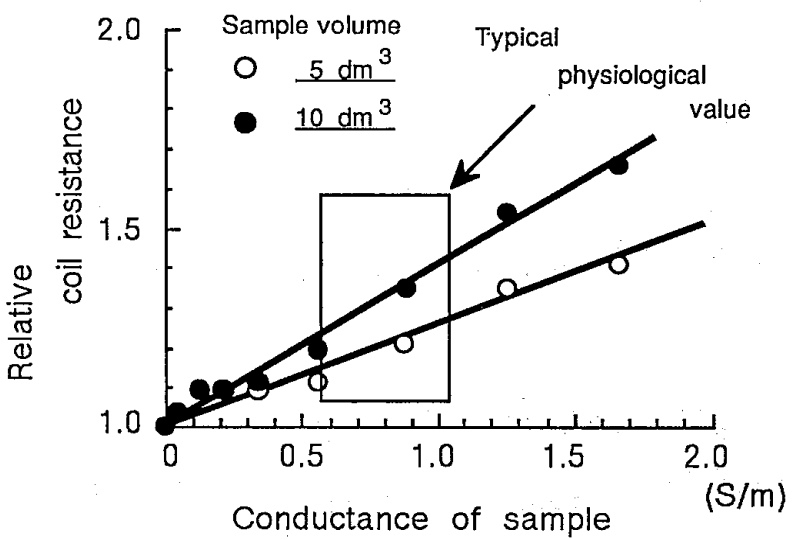

Fig. 1 Relation between electrical conductivity of the sample and coil resistance. Arrow : equivalent electrical conductivity values for human subjects. Sample solution: sodium chloride.

を測定した結果，0.55〜1.05 $\mathrm{Sm}^{-1}$ の範囲（Fig. 1）にあ った.

\section{2 理論の検証}

\section{2 .1 誘導損失性抵抗（コイル抵抗）}

サンプル半径に打けるコイル抵抗の測定結果を Fig. 2 に示す。サンプルの電気伝導率が大きい注ど，コイル抵 抗の増加率が大きかった。サンプルの単位半径における コイル抵抗の増加率は, 全身用コイルよりも頭部用コイ ルの方が大きかった.また filling factor (RF コイルの体 積中に占めるサンプルの体積の割合）が10\%（頭部用コ

Table 1 Simple Regression for 1. sample conductivity, 2. inductive loss, 3. signal-to-noise ratio (SNR) and 4. human losses.

\begin{tabular}{|c|c|c|c|c|c|c|c|}
\hline & Studies & Relation & Parameter & $\begin{array}{l}\text { Correlation } \\
\text { coefficient (R) }\end{array}$ & $\mathrm{R}$-squared & t-value & $\begin{array}{c}\text { Durbin } \\
\text {-Watson test }\end{array}$ \\
\hline \multirow[t]{2}{*}{1} & \multirow{2}{*}{$\begin{array}{l}\text { Sample } \\
\text { conductivity }\end{array}$} & \multirow{2}{*}{$\begin{array}{l}\text { Coil resistance } \\
\text { and conductivity }\end{array}$} & $5 \mathrm{dm}^{3}$ & 0.96 & 0.93 & 7.97 & 1.660 \\
\hline & & & $10 \mathrm{dm}^{3}$ & 0.99 & 0.98 & 16.17 & 1.144 \\
\hline \multirow{2}{*}{\multicolumn{2}{|c|}{$\begin{array}{l}\text { 2. Inductive loss } \\
\left(\text { sample }=0.8 \mathrm{Sm}^{-1}\right)\end{array}$}} & \multirow{2}{*}{$\begin{array}{l}\text { Coil resistance and } \\
\text { sample radius } 5\end{array}$} & Head coil & 1.00 & 1.00 & 19.58 & 2.474 \\
\hline & & & Body coil & 0.97 & 0.95 & 5.91 & 2.406 \\
\hline \multirow{2}{*}{\multicolumn{2}{|c|}{ 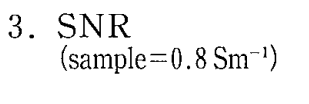 }} & \multirow{2}{*}{$\begin{array}{l}\text { SNR } 2 \text { and } \\
\text { sample radius }-5\end{array}$} & Head coil & 0.90 & 0.82 & 2.11 & 2.993 \\
\hline & & & Body coil & 0.95 & 0.91 & 3.10 & 2.990 \\
\hline \multirow{3}{*}{\multicolumn{2}{|c|}{$\begin{array}{l}\text { 4a. Human losses } \\
\text { for head coil }\end{array}$}} & \multirow{3}{*}{$\begin{array}{l}\text { Coil resistance and } \\
\text { sample radius }{ }^{5}\end{array}$} & Head & 0.90 & 0.80 & 16.73 & 1.984 \\
\hline & & & Neck & 0.80 & 0.64 & 5.02 & 1.028 \\
\hline & & & Knee & 0.80 & 0.64 & 2.00 & 1.249 \\
\hline \multirow{3}{*}{\multicolumn{2}{|c|}{$\begin{array}{l}\text { 4b. Human losses } \\
\text { for body coil }\end{array}$}} & \multirow{3}{*}{$\begin{array}{l}\text { Coil resistance and } \\
\text { sample radius } 5\end{array}$} & Chest & 0.82 & 0.68 & 3.54 & 2.546 \\
\hline & & & Abdomen & 0.81 & 0.66 & 2.98 & 2.060 \\
\hline & & & Pelvis & 0.86 & 0.73 & 7.20 & 2.557 \\
\hline
\end{tabular}


a) Head coil

b) Body coll

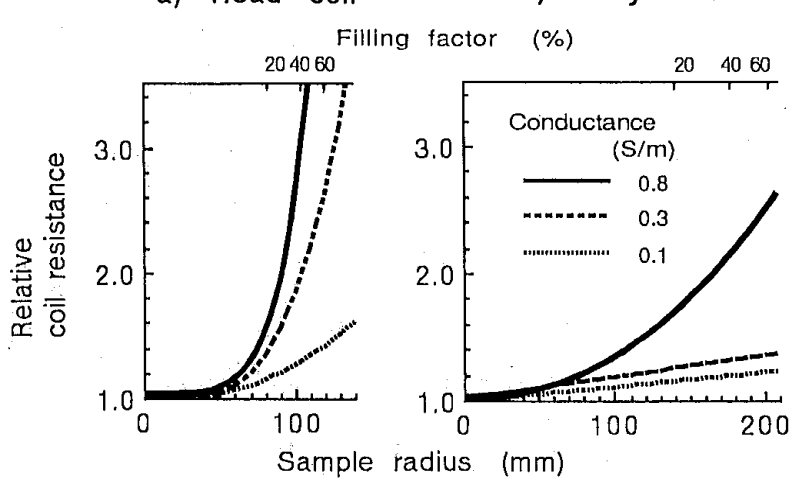

Fig. 2 Relation among sample radius, filling factor and coil resistance for a) head coil and b) body coil. Sample solution : three different electrical conductivities $0.8,0.3,0.1 \mathrm{Sm}^{-1}$ copper sulfate.

a) Head coil

b) Body coil

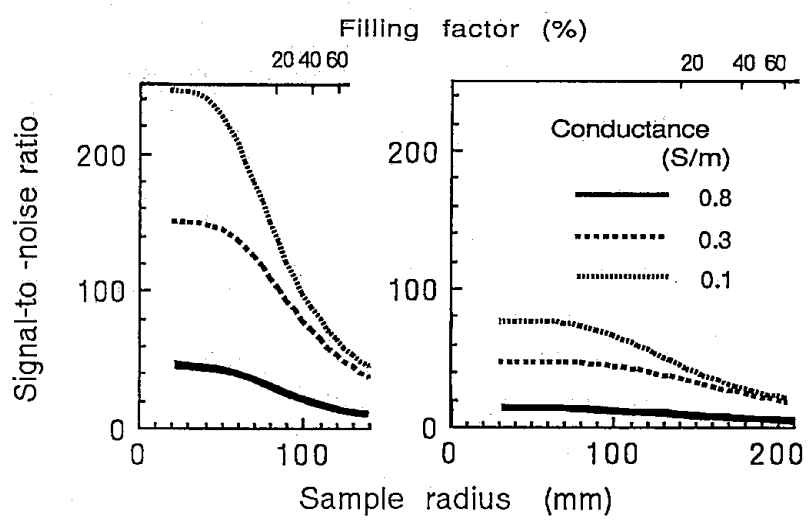

Fig. 3 Relation among sample radius, filling factor and signal-to-noise ratio for a) head coil and b) body coil. Sample solution : copper sulfate (three different electrical conductivities $0.8,0.3,0.1$ $\mathrm{Sm}^{-1}$.

イル‥サンプル半径 $56 \mathrm{~mm}$, 全身用コイル…ンプル半 径 $98 \mathrm{~mm}$ ）まで，兩コイルにおいてコイル抵抗の增加率 に大きな差を認めず，10\%を越えると頭部用コイルの方 が大きくなった、コイル抵抗のデータをサンプルの半径 の 5 乗に回帰した結果, Table 1 の 2 のごとくなった.

\section{$3.2 .2 \mathrm{SN}$ 比}

サンプル半径における画像 SN 比の測定結果を Fig. 3 に示す。サンプルが小径なほど，画像 SN 比は高く，頭 部用コイルと全身用コイルの画像 SN 比の差が大きか った。サンプル半径の増加に伴うSN 此の低下の割合 は，頭部用コイルの方が大きかった。画像 SN 比のデー タの 2 乗を, サンプル半径のー 5 乗に回帰した結果,

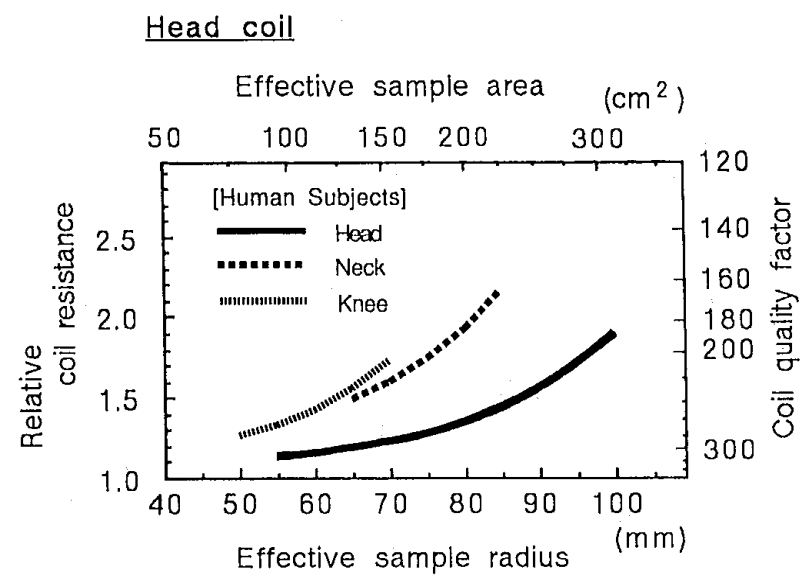

Fig. 4 Standard curve for human losses with a head coil. Values for human loss are displayed in relation to coil resistance and quality factor values along with measurements for the effective sample radius and area. Respective measurements for the head, neck and knee are provided.

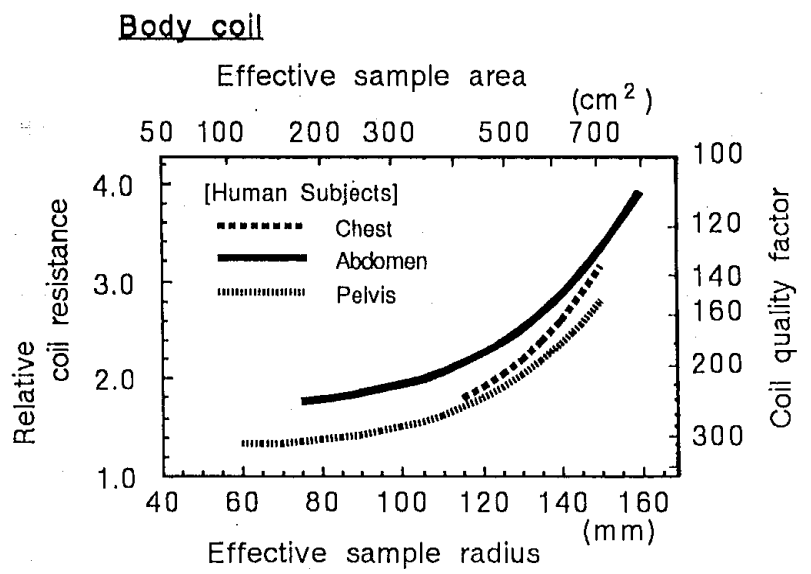

Fig. 5 Standard curve for human losses with a body coil. Respective measurements for the chest, abdomen and pelvis are provided.

Table 1 の 3 のごとくなった.

\section{3 臨床適応}

臨床画像をモニタして得たデータに，理論を適応させ て求めた損失值の標準曲線（各部位における実効半径と コイル抵抗の関係) を Fig. 4 ならびに Fig. 5 に示す. 頼 部用コイルの場合 (Fig. 4), 臨床データは無負荷時のコ イル抵抗の 1.1 倍から 2 倍の範囲に存在した.コイルの抵 抗值扔よび実効半径における抵抗值の増加率は, 頚部, 㴝部に比較して頭部が最も小さくなった.

全身用コイルの場合（Fig. 5)，臨床デー夕は無負荷時 のコイル抵抗の1.2倍から4倍の範囲に存在した.コイル 
の抵抗值は腹部が最も大きく, 以下胸部, 骨盤部の順で あった。また実効半径におけるコイルの抵抗の増加率は 胸部が最も大きく，腹部と骨盤部は同等であった。

実効半径におけるコイル抵抗のばらつきは，頭部が最 も小さかったが(標準誤差0.06)，その他の部位において も，頭部と䫒著な差は認められなかった（Table 1.4a， $1.4 b)$.

\section{4. 考察}

\section{1 実 験 系}

\section{1 .1 実験条件}

今回の実験において対象としたサンプル損失は，伝導 性サンプルに生じた渦電流による誘導損失性抵抗（磁気 損失性抵抗）である、コイル中サンプルによるコイル抵 抗の増加は，直接誘導損失の増加を示している. 生体の 損失には，誘導損失の他にコイルの電場との結合による 誘電性の損失 ${ }^{1)}$ がある。しかし被検体の大きさと損失の 関係の実験には, 誘電損失が直接関係なく, 誘電損失が 誘導損失に比較してわずかで無視できうる 点から取り上げなかった。ただし磁場強度が一層高い場 合, 誘電損失ならびに RF 磁場浸透性の影響らも問題と なるので，含めて検討する必要があると考える.

予借測定に扔いては，人体等価の電気伝導率を求める ために塩化ナトリウム溶液を使用した。しかし，理論の 検証実験の SN 比測定に扔いては，塩化ナトリウム溶液 の T1が延長しすぎて NEMA Standards の条件) を満 足しない。よって理論の検証の実験では，NEMA Standards を満足させる一定の T1值を得るために, 硫酸銅溶 液に硫酸を加えて電気伝導率の調整を行なって測定した。

\section{1 .2 理論の検証}

実験の全項目に扔いて，決定係数が0.8以上であり，ま た $\mathrm{t}$ 值が 2 以上，ダービンワトソン統計量6) が 1 以上 3 以下であった (Table 1.1，1.2，1.3). 回帰係数の統計的 な有意性を測るのが $\mathrm{t}$ 值（回帰係数/標準誤差）であり， 一般に $\mathrm{t}$ 值が 2 以上で回帰係数が有意であるとみなすこ とができる。またダービンワトソン統計量は回帰分析の 残差の自己相関の度合を測り，2 亿近い値ほど残差に自 己相関がないといえる。これより, 磁場強度 $0.5 \mathrm{~T}$ の MRI においても, 誘導損失がサンプル半径の 5 乗および サンプルの電気伝導率に比例し, 画像 SN 比の 2 乗がサ ンプル半径の 5 乗に反比例することが判明した。

\section{1 .3 受信感度の上限扔よび下限}

サンプル径抢よびRF コイル径の受信感度への寄与に ついて以下に述べる。人体と等価電気伝導率のサンプル
において，全損失中に占める誘導損失の割合は, Fig. 6 の ごとくなる. Rm は誘導損失, Rc は RF コイル自体の損 失を示し, 誘導損失の占める割合は， $(\mathrm{Rm} /(\mathrm{Rm}+$ Rc) ) $\times 100$ (\%) から算出した。両コイルを同一サンプル 半径において比較するなら，相対的に filling factor が大 きくなる頭部用コイルの方が誘導損失の占める割合は大 きく, 半径の増加に伴ってその差は一層広がる.よって $\mathrm{RF}$ コイル径の小さい頭部用コイルの方が, 誘導損失の 影響が大きいことが判明した。一方，両コイルを同一 filling factor において比較するなら, filling factor 10\% (頭部用コイルのサンプル半径 $56 \mathrm{~mm}$ ，全身用コイルの サンプル半径 $98 \mathrm{~mm}$ ）以下の場合，誘導損失の占める割 合は峏コイルともに小さい（頭部用コイル $7 \%$, 全身用 コイル15\%)。この場合, 画像 SN 比はコイルに大きく依 存するため，小径である頭部用コイルの方が約 3 倍優れ ていた(Fig. 3).しかし, サンプル半径が增加して filling factor が60\%以上になると，RF コイル自体の損失より もサンプルの損失が主となる (Fig. 2)。その結果，頭部 用コイルと全身用コイルの画像 SN 比の差が45\%以下 になった（Fig. 3)。このことは，コイル中に伝導性サン プルがない場合に，コイルの性能に依存する受信感度の 上限と，コイルにサンプルが充満している場合に，サン プルに依存する受信感度の下限が存在することを意味し ている。

\section{2 臨床}

\section{2 .1 臨床適用}

各部位60個の臨床デー夕に扔いて，実験系と同様にコ イル抵抗を実効半径の 5 乗の上に回帰させた。その結果，

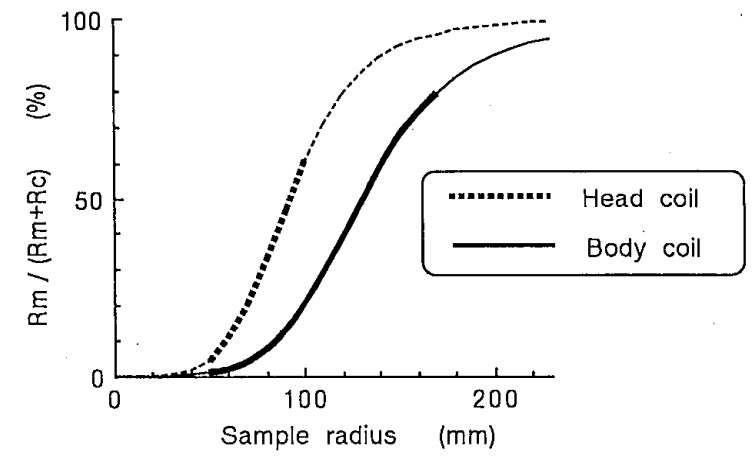

Fig. 6 Proportional inductive loss for head coil and body coil. Solid line: functionally usable range. $\mathrm{Rm}$ : magnetic resistance (inductive loss). Rc: resistance of the RF coil itself (coil loss). Sample: 0.8 $\mathrm{Sm}^{-1}$ copper sulfate solution. 
全部位とも, 相関係数が 0.8 以上, $t$ 值が 2 以上, ダービ ンワトソン統計量が 1 以上 3 以下（Table 1.4a, 1.4b）で あったので，推定した回帰式は統計的に優位であり，理 論は生体においても適用可能であるといえる。この部位 別の回帰式を, Fig. 4, Fig. 5 に示す人体の損失の標準曲 線とした。たしかに，生体と実験サンプルの半径が同一 な場合でも，人体の形状，組成等の不確定要素のために， 誘導損失の值は生体と実験サンプルの間で一致しないが， しかし両者共，同一の関数に扔いて誘導損失を表現でき ることが判明した。

\section{2 .2 誘導損失の部位別特徵}

人体の損失の標準曲線に扔いて，誘導損失の值および 増加率が各部位ならびに RF コイルによって特幑的であ ることが判明した，頭部用コイルにおいて，損失值なら びに損失の増加率は，頭部よりも頝部および膝部の方が 大きい（Fig. 4)．これは頭部よりも頝部および膝部の方 が, 脂肪組織がはるかに多いために, RF コイルとのカッ プリングがより強くなるからであると考えられる。全身 用コイルに扔いては，部位による損失の差は頭部用コイ ルほどなかったが，結果に示したように損失および損失 の増加率が，部位によって特徵的であることが判明した (Fig. 5).

このように誘導損失が部位によって異なり，実験で使 用した人体等価サンプルと一致しない場合があったが, 臨床結果を逆に実験系に還元すれば, 電気的に人体の各 部位に相当するファントムの作製も可能となる。

\section{2 .3 コイルパラメータの設定}

各部位の損失值の算出結果を応用して，実用的なコイ ルパラメータの設定を行なった。 RFコイルの自動チュ ーニング機構は以下のごとくである. コイル周波数，電 圧，共振曲線のスパンをシンセサイザでモニタし，ステ ッピングモータによって可変コンデンサのチューニング 容量とマッチング容量を一定の比率を持たせながら段階 的に調律方向に向けて変化させる。そしてコイル周波数 が共鳴周波数の $10 \mathrm{kHz}$ 以内で電圧のレスポンスが 28 $\mathrm{dB}(200 \mathrm{mV})$ 以下になった場合に，自動チューニング完 了としている。これまではチューニング容量, マッチン グ容量の初期值は，コイルごとに一定值としていた。部 位およびその寸法によってコイル負荷が初期值と大きく 異なる場合, 自動チューニングに時間を要し,まれに自 動チューニングが不能になる。そこで実験で得たデータ から，頭部用コイルに扔いて無負荷時の約1.2倍，1.5倍， 2.0 倍の負荷，全身用コイルにおいて無負荷時の約 1.3 倍, 2.6倍，3.8倍の負荷に見合ったチューニング容量および
マッチング容量を初期值として各々設定した.スキャン 前に損失の標準曲線（Fig. 4, Fig. 5) を参照し，目的部 位およびその寸法に合わせてチューニング容量とマッチ ング容量の初期值（各コイル 3 種類）を選択するように した結果，自動チューニングが迅速化された。

\subsection{4 画質管理}

コイル自体の損失 Rc と誘導損失 $\mathrm{Rm}$ から得る誘導損 失の増加率は, 次に示すようにコイル自体のQ $(\mathrm{Qe})$ と コイル中にサンプルが伴った場合のQ（Q1) の比から簡 便に求められる。

5 式よりサンプルの負荷がある場合は，

$$
\mathrm{Rc}+\mathrm{Rm}=\frac{1}{\nu \mathrm{lClQ1}}
$$

またサンプルがコイル中にない場合は，

$$
\mathrm{Rc}=\frac{1}{\nu \mathrm{eCeQe}}
$$

6 式および 7 式より

$$
\frac{\mathrm{Rc}+\mathrm{Rm}}{\mathrm{Rc}}=\frac{\nu \mathrm{eCeQe}}{\nu 1 \mathrm{ClQ} 1}
$$

通常 $\nu \mathrm{eCe} \fallingdotseq \nu 1 \mathrm{Cl}$ となるから誘導損失の増加率は,

$$
\frac{\mathrm{Rc}+\mathrm{Rm}}{\mathrm{Rc}} \fallingdotseq \frac{\mathrm{Qe}}{\mathrm{Q} 1}
$$

したがって臨床画像においてQをを観察すれば，誘導損 失をおおよそ把握可能であり，損失の標準曲線にはQも 付随して表示した (Fig. 4,Fig. 5)。ただし, RF シール ド材を使用する7など，金属が人体に装着されている場 合は，誘電損失も関係 ${ }^{1,2)}$ するので，Qだけで誘導損失を 評価するのは危険である。

実際に，損失の標準曲線の Q によって臨床画像の画質 管理を行なった例を示す，使用している MRI 装置はス キャンごとに Q等のモニタが可能であり，画像データに 付随させることができる，臨床において雑音が目立つ画 像 (頭部) が出現したので，スキャンデー夕を確認する と $\mathrm{Q}$ が155であった。被検者の頭部の実効半径は約 90 $\mathrm{mm}$ であったので，Qの標準值は損失の標準曲線（Fig. 4）から 222 となり，明らかにQQ標準值より低い值を示 した。被検者は約 3 箇月ごとに経過観察していたために $\mathrm{Q}$ の比較が容易であり，Qが低いのは被検体に起因する ものでないことが明白となった（Fig.7）.Fig.7に示す ように, 正常な場合は $\mathrm{Q}$ が標準值の $5 \%$ 有意水準内にあ るが，矢印で示した異常時は有意水準から大きく離れて いた。 原因を調べた結果，コンデンサがリークしていた ためであった。

画質管理は一定のファントムをスキャンして行なうの 


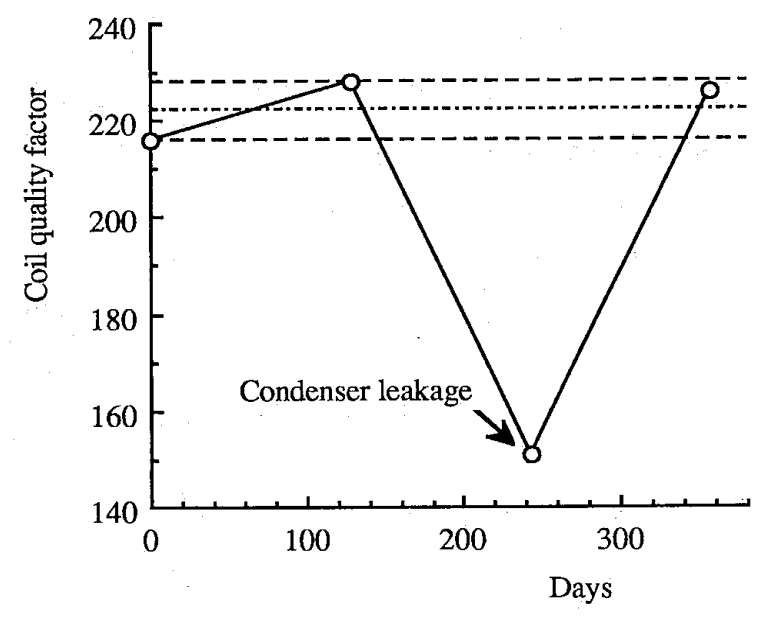

Fig. 7 Shifts in the coil quality factor for the head of the same patient. Dotted line indicates typical value and $95 \%$ confidence intervals for the effective sample radius. Arrow: the case of condenser leaking.

が最も望ましいが，ファントムを使用して検查ごとに画 質を確認するのは現実的に非常に困難である。しかし上 記のように人体の損失を把握した後で，臨床において Q をモニタしていれば，画質が低下した場合等に原因を検 索するための一手段となりうることが判明した。

\section{5. 結 論}

0.5 T-MRI の笑験系において, 誘導損失はサンプル半 径の 5 乗抢よびサンプルの電気伝導率に比例し, 画像 $\mathrm{SN}$ 比の 2 乗はサンプル半径の 5 乗に反比例しており,

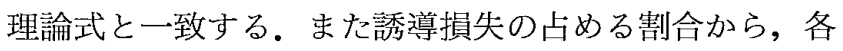
コイルにおける受信感度の上限および下限の算出が可能 である。

実験系の理論は，臨床においても適応可能である．誘
導損失は部位によって特徵的であり，人体の各部位にお ける誘導損失の算出によって，笑用的なコイルパラメー タの設定および画質管理が可能である。

本論文の要旨法日本放射線技術学会第17回秋季学術大 会にて報告した.

\section{文献}

1) D.I. Hoult, Paul C. Lauterbur.: The Sensitivity of Zeugmatographic Experiment Involving Human Samples., J. Magnetic Resonance, 34, 425 -433, (1979).

2) C. Leon Partain, Ronald R. Price, James A Patton, et al.: Magnetic Resonance Imaging, 2, 1183-1200, W.B. Saunders Company, Philadelphia, (1988).

3) R.M. Dowben.: General physiology. 358, Harper \& Row, New York, (1969).

4) National Electrical Manufactures Association: Determination of Signal-Noise Ratio in Diagnostic Magnetic Resonance Images., NEMA Standard Publication, MS 1, (1989).

5) P.A. Bottomley, E.R. Andrew. : RF Magnetic Field Penetration, Phase Shift and Power Dissipation in Biological Tissue: Implications for NMR Imaging., Phys. Med. Biol., 23, 630-643, Great Britain, (1978).

6）岩田曉一,木下宗七：テキストブック統計学, p. 234 -238，有斐閣ブックス，東京，(1989)。

7）宮地利明，八神祐司，荒木克已，他：Aliasing artifact の除去について（RF シールド材の利用法及び 適応範囲の検討)。日放技学誌，44（8，1045, (1988). 